\title{
TOLERATED DOSES OF PHENACETIN IN RELATION TO BODY WEIGHT AND ORGAN WEIGHTS
}

\author{
ELDON M. BOYD AND G. J. KRIJNEN \\ Department of Pharmacology, Queen's University, Kingston, Onlaria, Canada \\ Received for publication February 5, 1969
}

In a study of the clinicopathologic syndrome of toxicity to phenacetin at the rangc of the acute, oral $\mathbf{L D}_{50}$, Boyd in 1959 (1) used adult female rats and reported the $\mathrm{LD}_{50} \pm \mathrm{SE}$ to be $1.65 \pm 0.35 \mathrm{~g} / \mathrm{kg}$ body weight. In 1968 , Boyd and Hottenroth (2) studied the toxicity of phenacetin at the range of the oral $\mathrm{LD}_{50}$ (100 days) and reported the acute oral $\mathrm{LD}_{50}$ $\pm \mathrm{SE}$ in young male albino rats to be $4.14 \pm 0.71 \mathrm{~g} / \mathrm{kg}$. Boyd and Hottenroth (2) also reported that female rats were more sensitive to the lethal effects of daily administration of phenacetin than were male rats. In a comparison of the acute oral $\mathrm{LD}_{50}$ in young male and female rats, sex of the animals was found to have no influence on the median lethal dose. To find a reason for these apparently contradictory results, it was decided to measure the clinicopathologic syndrome of toxicity to singlc oral doses of phenacetin, after methods reviewed by Boyd (3), in male and female albino rats from the age of weaning to that of middle-aged, 1 to 1.5 year old, adults. Over this interval of time, certain organs comprise changing percentages of body weight. Since values for the $\mathrm{LD}_{s 0}$ arc normally expressed as $\mathrm{g}$ per $\mathrm{kg}$ body weight, it was decided to calculate $\mathbf{L D}_{\mathbf{5} 0}$ values in addition as $\mathrm{g} / \mathrm{kg}$ organ weights. Any organ in which variation in the $\mathrm{LD}_{s 0}$ so calculated was less than variation calculated as $\mathrm{g} / \mathrm{kg}$ body weight, could be concluded to be more concerned with tolerance to lethal doses of phenacetin than is total body weight.

\section{METHODS}

The experiments were performed upon albino rats obtained from Canadian Breeding Laboratorics of St. Constant, Quebec, Canada. On the day before administration of phenacetin, there were 50 to $5 \bar{j}$ animals in each of the following groups each expressed as mean \pm standard deviation grams body weight: (a) males; $66 \pm 9,120 \pm 8,188 \pm 18$, $300 \pm 10,420 \pm 32$ and $549 \pm 30$ and (b) females; $67 \pm 5,117 \pm 9,207 \pm 8,235 \pm 19,246$ $\pm 9,416 \pm 27$ and a group of pregnant females weighting $322 \pm 72 \mathrm{~g}$. The animals were placed in metabolism cages, one rat per cage, and given water but no food for 16 hours (overnight). Next morning each group was divided into six dosage subgroups, each subgroup given a dose of phenacetin estimated from pilot studies to produce a mortality rate just above 0 percent to just below 100 percent.

Phenacetin, U.S.P. was freshly prepared as a suspension in distilled water, with the aid of $0.2 \%$ gum trageacanth as a suspending agent, and given through an intragastric cannula in a constant volume of $20 \mathrm{ml} / \mathrm{kg}$ body weight. The animal was then returned 
to its metabolism cage and given food (Rockland Mouse/Rat Diet Complete) and water ad libitum. Clinical signs of intoxication were recorded by cageside observation at intervals of 24 hours for 5 days. Gross pathology was noted on all animals which died and histopathology was assessed upon the organs listed in Table 2 in representative animals of each group.

The wet weight and water content of the organs listed in Table 4 were measured in 15 other animals of each body weight group at 48 hours after giving $20 \mathrm{ml} / \mathrm{kg}$ of distilled water containing no phenacetin. The details of method and statistical analysis have been reviewed by Boyd (3).

\section{RESULTS $\Lambda$ ND DISGUSSION}

Values for the $\mathrm{LD}_{50}$ calculated as $\mathrm{g} / \mathrm{kg}$ body weight have been plotted against body weight in Fig. 1. It is apparent that the $\mathrm{LD}_{50}$ declines in both malc and female rats as adult wcight is reached.

Values for estimates of the intensity of clinical signs of intoxication are summarized

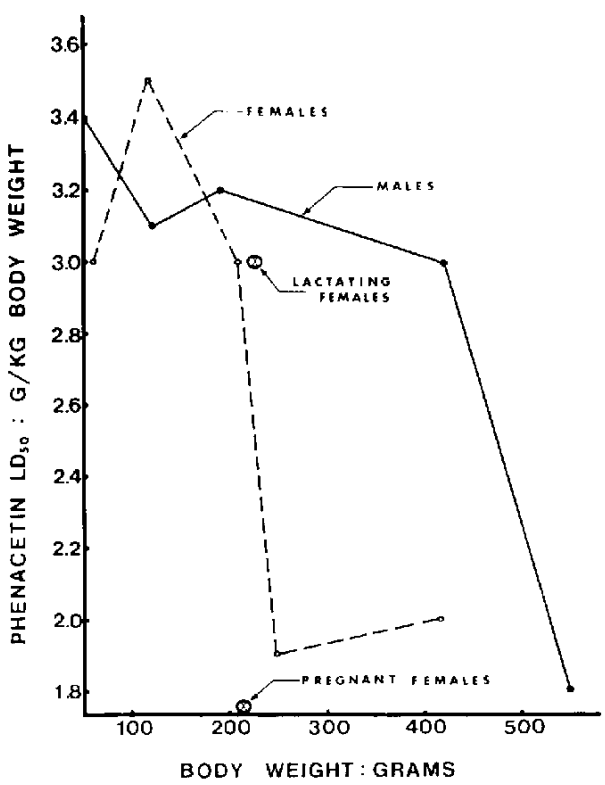

FIG. 1. The acute oral $\mathrm{LD}_{50}$ of phenacetin in relation to body weight of male and female albino rats.

Table 1. An analysis of clinical signs during intoxication to phenacetin at the range of the oral $\mathrm{LD}_{50}$.

\begin{tabular}{|c|c|c|c|}
\hline Clinical sign & $\begin{array}{c}\text { Mean } \perp \text { S.D. } \\
\text { (clinical units) }\end{array}$ & $\begin{array}{l}\text { Sign in males } \\
\text { more or less } \\
\text { marked than } \\
\text { in females at } \\
\mathbf{P}<0.02\end{array}$ & $\begin{array}{l}\text { Itensity of sign } \\
\text { increased or } \\
\text { decreased with } \\
\text { increase in body } \\
\text { weight at } \mathrm{P}<0.02\end{array}$ \\
\hline Listlessness & $2.5 \pm 0.6$ & No & Increased \\
\hline Decreased response to stimuli & $2.5 \pm 0.6$ & No & No \\
\hline Dacryorrhea & $1.0 \div 0.1$ & No & No \\
\hline Ataxia & $0.9 \pm 0.3$ & No & No \\
\hline Exophthalmos & $0.9 \div 0.4$ & No & No \\
\hline Restlessness & $0.8 \doteq 0.3$ & No & No \\
\hline Soiling & $0.7 \pm 0.1$ & Leess & Increased \\
\hline Diarrhea & $0.5+0.1$ & No & No \\
\hline Piloerection & $0.5 \pm 0.2$ & More & Decreased \\
\hline Abdominal distension & $0.4 \pm 0.2$ & Less & Decreased \\
\hline Cyanosis & $0.3 \pm 0.1$ & More & Decreased \\
\hline Epistaxis & $0.3 \pm 0.1$ & More & Decreased \\
\hline Pallor & $0.3 \div 0.2$ & No & No \\
\hline Convulsions & $0.1 \perp 0.1$ & No & No \\
\hline Hours to death & $32 \pm 11$ & No & No \\
\hline
\end{tabular}


TABLE 2. A summary of histopathological findings at death due to oral administration of phenacetin to male and female albino rats of increasing body weight.

\begin{tabular}{|c|c|c|c|}
\hline Organ & Histopathology & $\begin{array}{ll}\text { Eff } \\
\text { Sex }\end{array}$ & $\begin{array}{l}\text { of } \\
\text { Age }\end{array}$ \\
\hline Adrenal glands & $\begin{array}{l}\text { Cortical sinusoids congested and lipoid } \\
\text { granules prominent; occasional cortical } \\
\text { necrosis. }\end{array}$ & No & No \\
\hline Brain & $\begin{array}{l}\text { Mild capillary congestion of the brain } \\
\text { and meninges. }\end{array}$ & No & No \\
\hline $\begin{array}{l}\text { Gastrointestinal tract } \\
\text { Cardiac stomach }\end{array}$ & Infiltrative ulcers in older rats. & No & Yes \\
\hline Pyloric stomach & $\begin{array}{l}\text { Irritant inflammation; necrotic ulcers } \\
\text { in older rats. }\end{array}$ & No & Yes \\
\hline Small bowel & $\begin{array}{l}\text { Capillary-venous congestion of the } \\
\text { lamina propria and occasionally sub- } \\
\text { mucosa. }\end{array}$ & No & No \\
\hline Cecum & $\begin{array}{l}\text { Capillary-venous congestion of the } \\
\text { lamina propria and occasionally sub- } \\
\text { mucosa. }\end{array}$ & No & No \\
\hline Colon & Mild congestion of the lamina propria. & No & No \\
\hline Heart & $\begin{array}{l}\text { Areas of capillary congestion in older } \\
\text { rats. }\end{array}$ & No & Yes \\
\hline Kidneys & $\begin{array}{l}\text { Congestion of the loop region ; cloudy } \\
\text { swelling, fatty degeneration and necrosis } \\
\text { of the convoluted tubules especially in } \\
\text { older rats. }\end{array}$ & No & Yes \\
\hline Liver & $\begin{array}{l}\text { Sinusoidal congestion in younger rats; } \\
\text { cloudy swelling, fatty degeneration and } \\
\text { necrosis of the hepatic cells in older rats. }\end{array}$ & No & Yes \\
\hline Lungs & Areas of edema and congestion. & No & No \\
\hline Muscle (ventral abdominal wall) & Normal appearance & No & No \\
\hline Ovaries & Occasionally congestion. & - & No \\
\hline Pancreas & Normal appearance. & & \\
\hline Salivary (submaxillary) glands & Normal appearance. & No & No \\
\hline Skin & Ischemic in older rats. & No & Yes \\
\hline Spleen & $\begin{array}{l}\text { Contraction of red pulp; phagocytized } \\
\text { debris. }\end{array}$ & No & No \\
\hline Testes & Mild interstitial edema in older rats. & - & Yes \\
\hline Thymus gland & Congestion and loss of thymocytes. & No & No \\
\hline Uterus & Normal appearance. & - & No \\
\hline
\end{tabular}

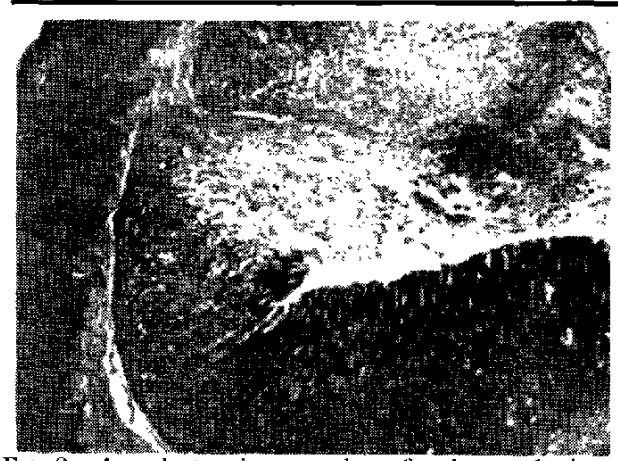

Fig. 2. A photomicrograph of the pyloric stomach of an adult female rat which died at 50 hours after oral administration of phenacetin in a dose of $3.0 \mathrm{~g} / \mathrm{kg}$ showing a hemorrhagic, infiltrative ulcer.

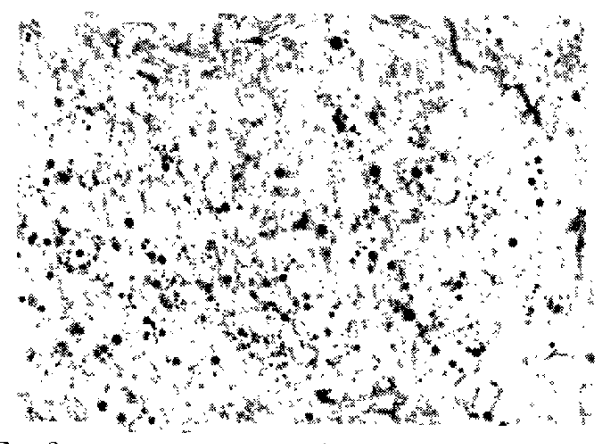

FIG. 3. s pruvinincrograph of the liver of an adult female rat which died at 52 hours after oral administration of phenacetin in a dose of $2.5 \mathrm{~g} / \mathrm{kg}$ showing diffuse fatty degeneration and pyknosis of some nuclei. 
TABLE 3. The $\mathrm{LD}_{\mathrm{50}}$ calculated as $\mathrm{g} / \mathrm{kg}$ organ weight.

\begin{tabular}{|c|c|c|c|c|c|c|}
\hline \multirow[t]{2}{*}{ Organ for calculation } & \multirow{2}{*}{$\begin{array}{l}\mathrm{LD}_{50} \text { in } \\
\text { males higher } \\
\text { or lower } \\
\text { than in } \\
\text { females }\end{array}$} & \multicolumn{2}{|c|}{$\begin{array}{c}\text { Change with } \\
\text { increase in body } \\
\text { weight }\end{array}$} & \multirow[t]{2}{*}{$\begin{array}{l}\text { Mean } \\
L_{50}\end{array}$} & \multirow[t]{2}{*}{$\begin{array}{l}\text { Standard } \\
\text { deviation }\end{array}$} & \multirow[t]{2}{*}{$\begin{array}{l}\text { Pearson's } \\
\text { coefficient of } \\
\text { variation }\end{array}$} \\
\hline & & Males & Females & & & \\
\hline Adrenal glands & Higher & None & None & 12,600 & 3,960 & 31.4 \\
\hline Brain & No & Increase & Increasc & 333 & 120 & 36.0 \\
\hline \multicolumn{7}{|l|}{ Gastrointestinal tissues } \\
\hline Cardiac stomach & No & None & None & 2,290 & 425 & 18.6 \\
\hline Pyloric stomach & No & None & None & 782 & 195 & 24.9 \\
\hline Small bowel & No & None & None & 190 & 60 & 31.5 \\
\hline Cecum & No & Increase & Increase & 698 & 196 & 28.1 \\
\hline Colon & No & Increase & Increase & 497 & 136 & 27.3 \\
\hline \multicolumn{7}{|l|}{ Gastrointestinal contents } \\
\hline Stomach & Lower & Increase & Increase & 203 & 64 & 31.5 \\
\hline Small bowcl & No & Increase & Increase & 91 & 18 & 19.8 \\
\hline Gecum & No & Increase & Increase & 146 & 28 & 19.2 \\
\hline Colon & No & None & None & 208 & 49 & 23.6 \\
\hline Total luminal contents & No & None & None & 33 & 6 & 18.2 \\
\hline Heart & No & None & None & 906 & 142 & 15.7 \\
\hline Kidneys & No & None & None & 346 & 55 & 15.9 \\
\hline Liver & No & None & None & 54 & 10 & 18.5 \\
\hline Lungs & No & None & None & 545 & 92 & 16.9 \\
\hline Muscle* & No & Decrease & Decrease & 247 & 90 & 36.5 \\
\hline Ovaries & - & - & None & 5,770 & 960 & 16.6 \\
\hline Salivary (submaxillary) glands & No & Increase & Increase & 1,820 & 370 & 20.3 \\
\hline Skin & No & Decrease & Decrease & 15.3 & 4.9 & 32.0 \\
\hline Spleen & Lower & None & None & 1,010 & 171 & 16.9 \\
\hline Testes & - & None & - & 313 & 68 & 21.7 \\
\hline Thymus gland & Higher & Increase & Increase & 3,890 & 2,450 & 63.0 \\
\hline Residual carcass & No & None & None & 5.6 & 2.0 & 35.7 \\
\hline Total body weight & $\begin{array}{l}\text { Higher at } \\
\text { maturity }\end{array}$ & Decrease & Decrease & 2.7 & 0.7 & 25.9 \\
\hline Live body weight** & $\begin{array}{l}\text { Higher at } \\
\text { maturity }\end{array}$ & Decrease & Decrease & 3.0 & 0.7 & 23.3 \\
\hline
\end{tabular}

* Right half of the skeletal muscular laycr of the ventral abdominal wall.

** Total body weight minus the weight of contents of the lumen of the gastrointestinal tract.

in Table 1. All of the signs appeared in male as well as in female animals and in old as well as in young animals. There were some significant $(\mathrm{P}<0.02)$ variations in intensity as noted in Table 1.

The histopathological findings are summarized in Table 2 and exemplified in Figs. 2 and 3. There were no differences due to sex of the animal. Gastric ulcers, myocardial congestion, renal tubular necrosis, hepatic necrosis, ischemia of the skin and edema of testicular interstitial tissue were more marked in older animals.

The $L_{50}$ expressed in $\mathrm{g} / \mathrm{kg}$ total body weight was divided by the number of grams of an organ per $\mathrm{kg}$ body weight and multiplied by 1,000 to obtained a value for the $\mathrm{LD}_{30}$ expressed as $\mathrm{g} / \mathrm{kg}$ organ weight. When so calculated, three types of relationship to body 


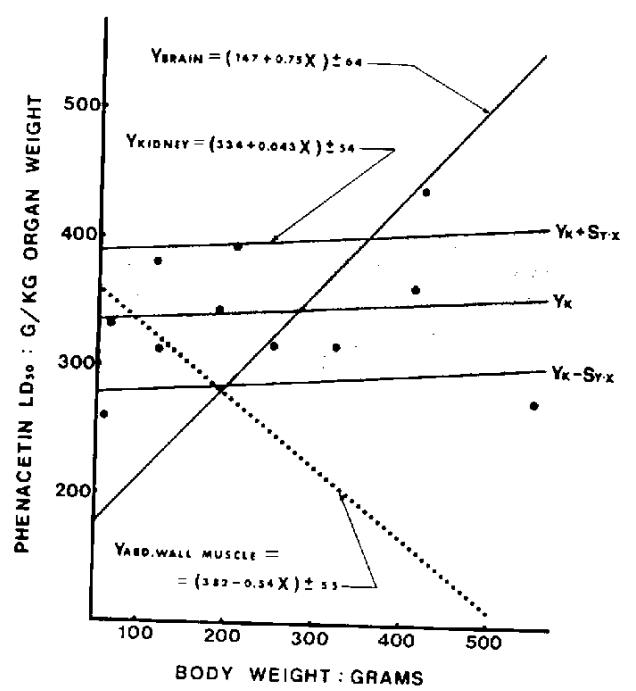

Fig. 4. The regression, on body weight, of values for the $\mathrm{LD}_{50}$ of phenacetin calculated as $\mathrm{g} / \mathrm{kg}$ brain weight, kidney weight and weight of ventral abdominal wall (right half) muscle. The regressions for brain are shown a calculated line for $\mathrm{Y}$ (brain) and for muscle as $\mathrm{Y}$ (muscle). The regressions for kidney is shown as actual values (solid circles), the calculated line for $\mathrm{Y}$ (kidney) and the calculated area (shaded) of $Y$ (kidney) plus and minus its standard error (Sy.x).

weight were encountered as exemplified in Fig. 4, e.g. positive correlation in brain, negative correlation in skeletal muscle and no correlation in kidney. Remaining values for the $\mathrm{LD}_{50}$ per $\mathrm{kg}$ organ weight are summarized in Table 3 as the mean \pm S.D. in all groups and the relation to sex and body weight. The results in males were the same as those in females for most organs. The $\mathrm{LD}_{\mathrm{n} 0}$ per $\mathrm{kg}$ of most organs was either not related to body weight or increased with increase in body weight with the notable exception of skeletal muscle and skin which decreased with increase in body weight.

This is explained inpart by data on organ weight calculated as $\mathrm{g} / \mathrm{kg}$ body weight and summarized in Table 4 . It is obvious from Table 4 that as body weight increased most organs comprised a smaller part of body weight with the exception of skeletal muscle and skin (and residual carcass which contained a large amount of skeletal muscle).

Data on water content of body organs are summarized in Table 5. It appears from thesc data that if the $\mathrm{LD}_{50}$ had been calculated as $\mathrm{g} / \mathrm{kg}$ dry weight of tissue the changes with age might have been more marked. Values for Pearson's coefficient of variation, which is the standard deviation expressed as a percentage of the mean, were lower for organ water content than for organ wet weight. Relationships due to calculation of $\mathrm{LD}_{50}$ vealus per kg organ dry weight would probably not be much different, therefore, than calculated per $\mathrm{kg}$ wet weight as in Table 3.

Values for Pearson's coefficient of variation of values for the $\mathrm{LD}_{50}$ per $\mathrm{kg}$ organ weight are assembled in the right hand column of Table 3. The coefficient for values of the $\mathbf{L D}_{50}$ 
TABLE 4. Organ weight calculated as g/kg body weight.

\begin{tabular}{|c|c|c|c|c|c|}
\hline Organ & $\begin{array}{l}\text { Index in males } \\
\text { more or less } \\
\text { than in females }\end{array}$ & $\begin{array}{l}\text { Change with } \\
\text { increase in } \\
\text { body weight* }\end{array}$ & Mean & $\begin{array}{l}\text { Standard } \\
\text { deviation }\end{array}$ & $\begin{array}{l}\text { Pearson's } \\
\text { coefficient of } \\
\text { variation }\end{array}$ \\
\hline Adrenal glands & Less & Decrease & 0.234 & 0.078 & 33.3 \\
\hline Brain & No & Decrease & 10.0 & 5.9 & 59.0 \\
\hline \multicolumn{6}{|l|}{ Gastrointestinal tissues } \\
\hline Gardiac stomach & More & Decrease & 1.22 & 0.32 & 26.2 \\
\hline Pyloric stomach & No & Decrease & 3.64 & 1.00 & 27.5 \\
\hline Small bowel & More & Decrease & 16.4 & 7.3 & 44.4 \\
\hline Cecum & More & Decrease & 4.12 & 1.20 & 29.2 \\
\hline Colon & No & Decrease & 5.28 & 2.04 & 38.5 \\
\hline \multicolumn{6}{|l|}{ Gastrointestinal contents } \\
\hline Stomach & More & Decrease & 15.0 & 6.7 & 44.7 \\
\hline Small bowe1 & More & Decrease & 30.6 & 9.8 & 32.0 \\
\hline Gecum & More & Decrease & 19.2 & 6.2 & 32.3 \\
\hline Colon & No & Decrease & 13.3 & 3.1 & 23.3 \\
\hline Total luminal contents & No & Decrease & 78.1 & 25.2 & 32.3 \\
\hline Heart & No & Decrease & 3.05 & 0.52 & 17.0 \\
\hline Kidneys & More & Decrease & 8.18 & 2.04 & 24.9 \\
\hline Liver & More & Decrease & 47.0 & 9.1 & 19.3 \\
\hline Lungs & Less & Decrease & 5.08 & 1.20 & 23.6 \\
\hline Muscle** & No & Increase & 11.7 & 2.3 & 19.7 \\
\hline Ovaries & - & $\begin{array}{l}\text { Increase } \\
\rightarrow \text { decrease }\end{array}$ & 0.45 & 0.06 & 13.3 \\
\hline Salivary (submaxillary) glands & No & Decrease & 1.57 & 0.40 & 25.5 \\
\hline Skin & No & Increase & 187 & 29 & 15.5 \\
\hline Spleen & More & Decrease & 2.81 & 1.00 & 35.6 \\
\hline Testes & - & $\begin{array}{l}\text { Increase } \\
\rightarrow \text { decrcase }\end{array}$ & 10.0 & 3.0 & 30.0 \\
\hline Thymus gland & No & Decrease & 1.12 & 0.58 & 51.8 \\
\hline Residual carcass & Less & Increase & 500 & 39 & 7.8 \\
\hline (Total body weight-g) & & - & $(250)$ & (127) & $(50.8)$ \\
\hline
\end{tabular}

* Results in males were similar to those in females.

** Right half of the skeletal muscular layer of the ventral abdominal wall.

calculated per $\mathrm{kg}$ total body weight was 25.9. The coefficient for certain organs such as adrenal glands, brain, small bowel, stomach contents, skeletal muscle, skin, thymus gland and residual carcass, was appreciably higher than 25.9 which suggested that the toxic action of phenacetin bore little relationship to the weight of these organs. The coefficient for other structures and organs such as cardiac stomach, the contents of the small bowel and cecum, heart, kidneys, liver, lungs, ovaries and spleen was appreciably less than 25.9 and the $\mathrm{LD}_{50}$ per $\mathrm{kg}$ organ weight had little or no relation to body weight suggesting that the lethal action of phenacetin bore more relationship to the weight of these than to total body weight.

A relationship to liver weight had been anticipated since the lethal dose of many drugs is related more to weight of the liver than to body weight (1). A relationship to renal 
TABLE 5. Organ water contents calculated as g water per $100 \mathrm{~g}$ dry weight of tissue.

\begin{tabular}{|c|c|c|c|c|c|}
\hline Organ & $\begin{array}{l}\text { Level in males } \\
\text { higher or lower } \\
\text { than in females }\end{array}$ & $\begin{array}{l}\text { Ghange with } \\
\text { increase in } \\
\text { body weight* }\end{array}$ & Mean & $\begin{array}{l}\text { Standard } \\
\text { deviation }\end{array}$ & $\begin{array}{l}\text { Pearson's } \\
\text { coefficient of } \\
\text { variation }\end{array}$ \\
\hline Adrenal glands & Higher & Decrease & 208 & 22 & 10.6 \\
\hline Brain & No & Decrease & 359 & 21 & 5.9 \\
\hline \multicolumn{6}{|l|}{ Gastrointestinal tissues } \\
\hline Cardiac stomach & Higher & Decrease & 297 & 29 & 9.8 \\
\hline Pyloric stomach & Higher & Decrease & 316 & 36 & 11.4 \\
\hline Small bowel & Higher & Decrease & 371 & 20 & 5.4 \\
\hline Cecum & Higher & Decrease & 363 & 79 & 21.7 \\
\hline Colon & Higher & Decrease & 368 & 33 & 9.0 \\
\hline Heart & No & Decrease & 340 & 10 & 2.9 \\
\hline Kidneys & No & Decrease & 341 & 14 & 4.1 \\
\hline Liver & No & Decrease & 252 & 9 & 3.6 \\
\hline Lungs & No & Decrease & 379 & 10 & 2.6 \\
\hline Muscle** & Higher & Decrease & 292 & 43 & 14.7 \\
\hline Ovaries & - & Decrease & 241 & 20 & 8.3 \\
\hline Salivary (submaxillary) glands & No & Decrease & 294 & 13 & 4.4 \\
\hline Skin & Higher & Decrease & 185 & 37 & 20.0 \\
\hline Spleen & No & Decrease & 331 & 17 & 5.1 \\
\hline Testes & - & None & 643 & 16 & 2.5 \\
\hline Thymus gland & Higher & Decrease & 310 & 92 & 29.7 \\
\hline Residual carcass & Higher & Decrease & 221 & 29 & 13.1 \\
\hline
\end{tabular}

* Changes in males were similar to those in females.

*: Right half of the skeletal muscular layer of the ventral abdominal wall.

weight might be expected in view of the renal elimination of phenacetin and its metabolites. Since phenacetin produces death by inhibition of respiration, a relationship to weight of the heart and lungs is reasonable. The relationship to ovarian weight may reflect apparent differences due to sex of animals in the toxicity of phenacetin although if so one might have expected a similar relation to testicular weight. The relationship to weight of splcen may be connected with the stress reaction produced by lethal doses of phenacetin but again if so one might expect a relation to weight of the adrenal and thymus glands which was not found. The relationship to weight of cardiac stomach and intestinal contents was not anticipated. It may be connected with evidence reviewed by Boyd (3) that the toxicity of many drugs is increased with increase in the volume of distilled water in which they are dissolved or suspended for intragastric administration. The greater the volume of water administered into the stomach with a drug under study, the greater would become the weight of the intestinal contents - at least until the water was absorbed-and, by evidence herein found, the greater would become the toxic action of the drug. The weight of intestinal contents may also affect the rate of absorpiton of phenacetin.

The results of this study are of significance in connection with various publications. For example, Kato et al. (4) reported that the effects of certain drugs in male SpragueDawley rats differed from those in females and that the difference disappeared when the liver was inhibited by SKF 525A. Kato et al. (5) found that the ability of the liver of 
female rats to metabolize certain drugs was greatest at age 30 days and gradually declined to age 150 days. Kato and Takanaka $(6,7)$ explained that the decline in drug metabolism in old rats was due to a decrease in the activity of hepatic drug-detoxifying enzymes in these old animals.

\section{SUMMARY}

The acute oral $\mathrm{LD}_{\mathfrak{s},}$ of phenacetin calculated as $\mathrm{g} / \mathrm{kg}$ body weight was identical in male and female rats but decreased as adult weight was reached in both sexes. Most of the clinical and pathological signs of toxicity were identical at all ages in both sexes. The apparent increase in the toxicity of phenacetin in adult animals was due mainly to an increase in the weight of muscle and skin per kg body weight. The $\mathrm{LD}_{50}$ calculated as $\mathrm{g} / \mathrm{kg}$ organ weight remained fairly constant in certain organs and did not vary with increase in body weight, suggesting that the toxicity of phenacetin is related to the weight of these key organs. The key organs were liver, kidneys, heart, lungs, ovaries (but not testes), spleen (but not adrenal and thymus glands), cardiac stomach, and curiously, weight of intestinal contents.

Acknowledgemnt: This project was assisted financially by the Food and Drug Directorate, Department of National Health and Welfare, Ottawa, Canada, and by Merck Frosst Laboratories of Montreal, Canada.

\section{REFERENCES}

1) Boyd, E.M.: Toxic. appl. Pharmac. 1, 240 (1959)

2) Boyd, E.M. And Нottenroth, S.M.H.: Toxic. appl. Pharmac. 12, 80 (1968)

3) Boyd, E.M.: Canad. med. Assoc. J. 98, 278 (1968)

4) Kato, R., Chiesara, E. and Frontino, G.: Biochem. Pharmac. 11, 221 (1962)

5) Kato, R., Vassanelli, P., Frontino, G. and Cihiesara, E.: Biochem. Pharmac. 13, 1037 (1964)

6) Kato, R. and Takanaka, A.: Jap. J. Pharmac. 18, 381 (1968)

7) Kato, R. and Takanaka, A.: Jap. J. Pharmac. 18, 389 (1968) 